\title{
THE ANTHROPOLOGICAL UNDERPINNING OF VYGOTSKY'S THINKING
}

- In the late 1920s Vygotsky (and Luria) developed a set of ideas that was to become well-known as the cultural-historical theory of the higher psychological processes. ${ }^{1}$ Currently different aspects of this theory are enjoying increasing popularity among developmental psychologists in both the Soviet Union and the West. Unfortunately, certain key ideas of Vygotsky's thinking have never been given a proper treatment in contemporary literature. More specifically, the presentation of Vygotsky's ideas tends to omit certain sensitive issues concerning the anthropological assumptions of the cultural-historical theory. The result is a selective and distorted view of Vygotsky as a historical figure of psychology.

One example is Vygotsky's and Luria's ${ }^{2}$ monograph, Studies in the History of Behavior. Ape. Primitive Child. As is obvious from its title this book deals with three developmental domains: 1) mental development from primates to the human species; 2) mental development from "savage" to modern European man; and 3) mental development from (European) child to adult. The basic idea of the book, that is seldom mentioned and not represented in either the Soviet or English version of Vygotsky's Collected Works, was that comparison of these three developmental domains might reveal interesting and useful parallels.

Nowadays similar views are advocated only by a few sociobiologists or ethologists, ${ }^{3}$ but are regarded rather skeptically by most psychologists. It would seem, then, that an open and critical discussion of Vygotsky's theory would benefit from a clear presentation of his views in this connection. In the following we will present an overview of Vygotsky's views regarding the second of the developmental domains mentioned above, that is, the development from "savage" to modern European man. More complete discussion of his views regarding the other developmental domains will be given elsewhere. ${ }^{4}$ 


\section{Basic Themes}

In the following we will present several of the key ideas of the highly complex and somewhat heterogeneous set of ideas known as culturalhistorical theory. This will allow us to see Vygotsky's treatment of ethnological findings in its proper context.

First, the theory implied a distinction among and a view of the three developmental domains mentioned before: a) the development from animals to the human species (or, phylogeny); b) the development from "primitive" man to modern man (i.e., history); and c) the development from child to adult (i.e., ontogeny). Distinguishing and comparing these different domains was not at all original at the time and basically originated in the general acceptance by Vygotsky's contemporaries of the evolutionary ideas put forward by Lamarck, Spencer, and Darwin. Such eminent thinkers as Bühler ${ }^{5}$ Freud, ${ }^{6}$ Kafka, ${ }^{7}$ Koffka, ${ }^{8}$ Kretschmer, ${ }^{9}$ Stern, ${ }^{10}$ and Werner ${ }^{11}$ all accepted the evolutionary point of view and made speculative cross comparisons between the various developmental domains. Freud, ${ }^{12}$ for example, argued that "primitive" tribes formed a "well-preserved preliminary stage of our own development." Twelve years later, the first volume of Kafka's Handbook of Comparative Psychology explicitly distinguished as developmental rungs of mental development (German: Entwicklungsstufen des Seelenlebens) the three domains mentioned above. ${ }^{13}$ Finally, some years later Koffka ${ }^{14}$ warned that "the subject whom we normally investigate in psychological research is the adult 'educated' Western-European, a being that, biologically speaking, stands on the latest rung." Thus, distinguishing and comparing these developmental domains was not original to Vygotsky and, in a sense, he did no more than follow in the footsteps of a powerful tradition of European thought.

Second, Vygotsky tried to link his view of the developmental domains to Marxist anthropology. This resulted in a specific view of, in particular, the transition from animal to human being. In general, Vygotsky accepted Darwin's account of evolution, and he had no problem with the idea that evolution from animals to man was a continuous process. But he did deny that this was the whole story, and he resisted Darwin's claim that "the mental faculties of man and the lower animals do not differ in kind, although immensely in degree." ${ }^{15}$ On the contrary, Vygotsky claimed that 
there were fundamental differences between animals and human beings, differences that originated with the onset of human culture. Whereas animals in his view are almost fully dependent on the inheritance of genetically based traits, human beings can transmit and master the products of culture. Mastering the knowledge and wisdom embodied in human culture, they can make a decisive step towards emancipation from nature. The specifically human traits, then, are acquired in mastering culture through the social interaction with others. Reasoning in this way, Vygotsky restricted the role of biological evolution and the genetic background of human behavior. Behavior did have a genetic background in his opinion, and this background had its origin in biological evolution, but it was restricted to what were called the lower psychological processes. The specifically human, higher psychological processes had developed in human history and had to be mastered anew by each human child in a process of social interaction.

This distinction between biological evolution and human history was based on the writings of Marx and, perhaps more importantly, Engels. Marx ${ }^{16}$ had, following Benjamin Franklin, defined man as "a toolmaking animal" and Engels in his study, "The part played by labor in the transition from ape to man" had elaborated this view. Vygotsky was well aware of Engels' account, first published in the Soviet Union in Dialectics of Nature, ${ }^{17}$ and repeatedly referred to it to explain the differences between animals and man.

Engels' account of the origin of Homo sapiens was rather crude, but not implausible in view of the available evidence. ${ }^{18}$ According to him the history of mankind originated when the precursor of man left the trees and developed an upright gait. This was a decisive step towards the transition from animal to man. ${ }^{19}$ The erect posture freed the hand for the manipulation of objects and allowed the development of finelytuned motor actions together with the development of visual processes. The result was a gradually improving eye-hand coordination and the development of the corresponding brain parts. The hands, sense organs, and brain developed in a complex interaction. As soon as man started cooperating in labor, he experienced the need for a means of communication. This, Engels argued, resulted in the development of speech. Labor, then, came first, and created in its turn the need for speech. ${ }^{20}$ Labor was defined by Engels and Marx as the defining characteristic of 
human beings. The origin of labor was the manufacture of the first primitive flint tools by our predecessors. Cooperation in groups, toolmaking, and communication through speech gradually led to the planned, deliberate, transformation of nature. Engels acknowledged that animals showed the beginning of conscious, planned action, just as Marx acknowledged their incipient tool use, but claimed a principal difference between animals and man: animals use nature, whereas human beings control nature.

In sum, Engels emphasized the manufacture and use of tools in the history of mankind and indicated that human beings displayed an essentially different relationship with the environment: instead of passively using its facilities, human beings actively transformed nature. Vygotsky accepted this account, indeed one might ask whether there was any room for dissent here in the 1920 s, and tried to integrate it in his theory of man. Accepting Engels' theory implied a distinction between biological evolution and human history and a strong emphasis on the role of tools and labor in the origin of human culture. One of the major challenges for Vygotsky would be to demonstrate how tool use and labor influenced the human mental processes.

The combination of contemporary anthropological and psychological insights with the Marxist world view was not without its problems. One problem left unsolved by Engels was that of the exact nature of the historical period. Can we reconstruct the history of Homo sapiens from "primitive" cultures up to contemporary man? Was it permissible to use cross-cultural evidence in this respect, assuming that current nonWestern peoples were somehow identical or similar to historical "primitive" man? These were questions that fascinated Vygotsky and his contemporaries, many of whom saw linear developments from ape to savage, and that could not be avoided in the grand theory that Vygotsky envisioned. In order to answer them he turned to the available ethnographic evidence provided by Durkheim, Lévy-Bruhl, and Thurnwald.

\section{Durkheim}

Vygotsky's understanding of other cultures and of the relation of culture to mental processes was based on his reading of Durkheim, 
Lévy-Bruhl and, most importantly, Thurnwald. Although he sometimes referred to Durkheim rather critically, ${ }^{21}$ it is easy to see why the ideas of the leader of the French sociological school would appeal to him. Firstly, Durkheim, like his contemporary Janet, ${ }^{22}$ took an explicitly genetic point of view. He defended the idea that any real explanation of complex social phenomena rested on the reconstruction of its development. ${ }^{23}$ Secondly, Durkheim resisted the idea that complex mental functioning can be derived from the individual. In his view each society embodied a set of "collective representations" that imposed themselves, much like Kantian categories, on the individual. These collective representations were the carriers of the accumulated experience of generations and generations of people. To Durkheim they were.

clever instruments of thought, that the human groups have ... forged in the course of centuries and where they have accumulated their intellectual capital. ${ }^{24}$

In Durkheim's opinion the collective representations were similar to tools, because these too represented accumulated capital. ${ }^{25} \mathrm{He}$ concluded that

To know from what the conceptions are made that we have not made ourselves, it would not suffice to question our consciousness: WE HAVE TO LOOK OUTSIDE OURSELVES, IT IS HISTORY WE HAVE TO OBSERVE. ${ }^{26}$

It is not at all difficult to see how this conception may have influenced Vygotsky. It is sufficient to replace "collective representations" by "higher mental processes" to recognize ideas that Vygotsky voiced on many occasions. This is not to say, of course, that cultural-historical theory is equivalent to Durkheim's approach. To Vygotsky and his students, for example, Durkheim did not provide a sufficient explanation of the origin of the collective representations, nor did he give an adequate psychological account of the way individuals acquired them. It can be seen, however, that Vygotsky, directly or indirectly through Lévy-Bruhl, adopted much of Durkheim's global approach.

\section{Lévy-Bruhl}

Part of the influence that Lévy-Bruhl exerted on Vygotsky should be attributed indirectly to Durkheim. Thus, Lévy-Bruhl ${ }^{27}$ shared Durk- 
heim's conception of the collective representations and claimed that the higher mental functions were unintelligible as long as one studied the individual. Lévy-Bruhl, however, also provided Vygotsky with many detailed descriptions of "primitive" thought, descriptions that Vygotsky used in his characterizations of "primitive" cultures and in his many comparisons of children with "primitives."

Lévy-Bruhl's influence is most clearly discernible in Studies of the History of Behavior. Ape. Primitive. Child. ${ }^{28}$ In the second chapter, Vygotsky related many of Lévy-Bruhl's findings and closely followed the latter's organization of the material. In the second paragraph of this chapter Vygotsky related Lévy-Bruhl's dispute with the British school in anthropology. Lévy-Bruhl ${ }^{29}$ criticized Tylor and Frazer for their assumption that the workings of the human mind are identical in every culture. He would at least leave open the possibility that the bewildering cultural variety of collective representations corresponded with different mental functions. Vygotsky completely agreed with this reasoning: accepting the point of view of British anthropology would imply acceptance of the idea that the human mind had not developed at all during human history. The sole differences between cultures would be in the content of experience, but the mechanisms of mind would be identical in every epoch and culture. ${ }^{30}$

Vygotsky acknowledged that Lévy-Bruhl was the first to claim that the mechanisms of "primitive" thinking did not coincide with those of "cultural man." Despite certain inaccuracies Lévy-Bruhl had to be credited for the fact, that

he first posed the problem of the historical development of thinking. He showed that in itself the type of thinking is not a constant unity, but one that changes and develops historically. The investigators who followed the road indicated by him have tried to formulate more precisely on what the difference between the historical types of thinking of cultural and primitive man depends, in what the peculiarity of the historical development of human psychology resides. ${ }^{31}$

We can see, then, that a fundamental idea of cultural-historical theory, namely the idea that people in different cultures and epochs have different higher mental processes, was present in the work of Lévy-Bruhl. It was this idea that Luria would try to corroborate in this expeditions to Uzbekistan. ${ }^{32}$ Again, the fact that Vygotsky used Lévy-Bruhl's ideas does not imply that he accepted the whole of his theory. Leaning on 
various critics he suggested that Lévy-Bruhl's characterization of the "primitive" collective representations as "prelogical" was unfortunate: seen from their subjective point of view they were completely logical. Durkheim's and Lévy-Bruhl's basic idea that the differences in mentality between people living in different cultures was not attributable to their individual capacities had another side to it. It implied that people living in "primitive" or "inferior" cultures were not necessarily intellectually inferior to Western people. Lévy-Bruhl, in particular, repeatedly emphasized that the "primitives" did not suffer from an intellectual indolence (torpeur intellectuelle), or a feebleness of spirit (faiblesse d'esprit). ${ }^{33}$ If they sometimes might seem stupid, this was but an "apparent stupidity," the result of the fact that our questions simply did not make sense to them. ${ }^{34}$ For, the collective representations of "primitives," constituted another world, a world that on a number of points did not coincide with ours. As a consequence, many of the questions Western man asked himself simply did not arise for them. ${ }^{35}$

The implication of this view was that one should not confront people from other cultures with tasks typical of our culture and then draw conclusions based on their possibly "poor" performance. For this would be to judge them by our Western standards and to see their thinking as a rudimentary form of ours, an approach that Lévy-Bruhl explicitly condemned. One can see, then, that Lévy-Bruhl's approach led to conclusions that were of great value to Vygotsky. Indeed, to affirm that people from different cultures have different higher mental capacities, but do not differ as regards basic capacities, is only one step from Vygotsky's statement that their higher mental processes differ, whereas the lower ones are identical. This view, incidentally, contradicted that of many of Lévy-Bruhl's contemporaries who were often inclined to attribute mental differences to innate capacities.

We can conclude, that Lévy-Bruhl provided Vygotsky with a fruitful way of thinking about the relation of culture to mental processes. In addition, he provided Vygotsky with many observations of the way "primitive people" think. These ethnographic observations were used by Vygotsky to reconstruct the historical development of human thinking and draw comparisons with human ontogeny. 


\section{Making Use of Lévy-Bruhl's Ethnographic Observations}

Vygotsky accepted, for instance, the findings Lévy-Bruhl, ${ }^{36}$ presented supposedly showing that the "primitive" people thought with concepts of a very concrete character. "Primitive" thought would not lead to the formation of concepts and scientific knowledge, ${ }^{37}$ a fact reflected in their comparatively underdeveloped language in which there are very few generic terms, but a wealth of concrete names for all sorts of objects. ${ }^{38}$ When "primitive" people did employ generic terms they were mostly of the "inadequate" family-concept type, that is, various instances of the concept overlapped, but there was not one feature they all shared. ${ }^{39}$ In many cases where we would use abstract concepts, "primitive" people relied on their prodigious memory, ${ }^{40}$ a phenomenon that reminded Vygotsky of Western children's behavior. In sum, LévyBruhl and Vygotsky agreed that "primitive" thinking is very concrete and, therefore, tied to the immediate situation. It is also more fused with emotions and visual impressions. Vygotsky would probably not have objected, had a contemporary said that these features of "primitive" thinking put it in an intermediate position between the ape's full dependency on the visual field and abstract, decontextualized, adult Western thinking. He did, in fact, compare the memory of "primitive" people to that of a Western child.

Nevertheless, Lévy-Bruhl's findings also showed that "primitive" people in "backward" cultures ${ }^{41}$ took recourse to artificially created stimuli in order to control their own behavior. Among the examples that Vygotsky related on several occasions was that of the Magololo chief who would solve an issue by dreaming about it; or throwing bones as a decision procedure ${ }^{42}$ and using body parts in counting. ${ }^{43}$ Vygotsky accepted all of these examples of various cognitive methods in contemporary non-Western cultures as indications that, historically, Western thought had gone through stages in which these methods had been prevalent. When visiting the Australian aboriginals, the Western ethnographer was visiting his own culture's past.

This conclusion again confronts us with the question whether Vygotsky adopted a simple evolutionary scheme after all and whether his cultural-historical theory was free of ethnocentrist ideas. To settle this question we will turn to his other major source of information 
about the mental functioning of "primitive" man: Thurnwald's Psychologie des primitiven Menschen.

\section{Thurnwald}

The German ethnologist's basic claim was that the modern (European) mind is superior to that of prehistoric man. This superiority could not be explained by differences in biological makeup, but had cultural origins. The mental superiority of present-day people was due to the invention and accumulation of cultural means and processes. Unfortunately, very little reliable knowledge was available about the culture and mind of prehistoric man. To illustrate his point of view, therefore, Thurnwald proposed to look at various non-Western cultures.

Such an approach raised various questions, as Thurnwald all too well realized. May one resort to the study of present-day, albeit nonWestern, people if one's goal is to study prehistoric man? Does the study of the culture, or cultural remnants, of people allow one to draw conclusions about the way these people think (thought)? Is the culture of Western man superior to that of contemporary non-Western, "natural," or "primitive" man? These were several of the questions that, ideally, had to be answered.

Thurnwald was not very clear about all of these issues, but he made, at least implicitly, four claims that shed some light on them. These were that 1) prehistoric man was the precursor of all present-day human beings; 2) the culture and mind of prehistoric man were similar to that of present-day "natural" man; 3) there was no difference in biological makeup between contemporary western and non-western, or "natural" man; and 4) the culture and mind of contemporary Western man were superior to that of non-Western man.

The first claim hardly needs any comment and will not be discussed here. With respect to the second claim, Thurnwald defended a cautious point of view, stating that similarities in one cultural feature (e.g., technology) cannot simply lead us to conclusions about similarities in mental makeup. But if one found many of these customs and products, then such conclusions seemed justified to him. ${ }^{44}$ Among the topics Thurnwald discussed were, among other things, the different types of communities in which people lived, the role of women in these 
communities, the various sorts of technologies in use, different types of economy, law, moral thinking, music, art, writing and language, counting systems, mythical thinking, and religion. His assumption was, an assumption that Vygotsky would turn into one of the cornerstones of his theory, that culture, as a means of control and knowledge of the surroundings, does not merely imply technological perfection, but also comprises cognitive abilities. ${ }^{45}$ Of course, Thurnwald touched a problem here that is still very much alive in present-day cross-cultural psychology.$^{46}$ All in all, Thurnwald did believe that it was possible, after careful consideration of many cultural phenomena, to draw conclusions about prehistoric culture and thinking on the basis of the study of present-day natural people.

Thurnwald's third claim was very relevant for Vygotsky's conception of the lower psychological processes. The question was whether the different cultures of natural people might not be explained by their different biological makeup. Several findings, such as early puberty among natives, seemed to indicate that these people indeed belonged to a different biological type. Contrary to many of his contemporaries, however, Thurnwald felt that the evidence was not conclusive. He did not exclude the possibility that such phenomena were caused by different cultural customs (e.g. food habits) and concluded that the existence of different biological types among present-day people had not been proved.

With respect to the fourth claim Thurnwald admitted that, of course, there was an enormous variety of present-day "primitive" or "natural" people. Moreover, these people were in no way primitive in the sense of not having any culture at all: they did have their own, albeit "poor," culture. In this respect, he remarked, they were much closer to European man than to apes. ${ }^{47}$ Nevertheless, Thurnwald argued, on the basis of our and their technological-intellectual performance we tend to think that we are culturally "more developed" than they are. We are inclined to call certain cultures "inferior," others "superior," and to discern certain "progressive" developments. The assumption, obviously, is that our mind depends historically on theirs and that our culture developed from theirs. This would imply that the culture of nonWestern people had come to a standstill in the past millennia. Studying non-Western people we would indeed study our own past. 
Thurnwald mentioned the idea, that different cultures might be actually incomparable on a linear scale. Rather surprisingly, he tended to agree with this point of view. Theoretically speaking, Thurnwald stated, ${ }^{48}$ one can only say that human culture branched out in different developmental directions, but subjectively the "accumulation" of knowledge and abilities is experienced by Western people, from their egocentric point of view, as progress. In practice, Thurnwald himself felt more inclined to the subjective point of view, and throughout his book he freely used terms like "poor" and "paltry" to characterize the cultures of non-Western people.

In sum, it is probably fair to say that Thurnwald was a moderate ethnocentrist. He clearly thought that Western cultures were superior to all other cultures, and that these latter cultures represented a stage of mental development Western people had long left behind. On the other hand, he admitted that from a, practically unattainable, objective point of view these different levels of culture might be viewed as equivalent cultural variants.

\section{Vygotsky and Thurnwald}

It is quite interesting to see which elements from Thurnwald's thinking Vygotsky accepted and which he simply ignored. The first thing that can be noticed is that Vygotsky fully shared the mild ethnocentrist position defended by Thurnwald. Vygotsky agreed with the idea that one can discern different levels of culture and viewed the study of people living in the "uncivilized world" as a legitimate means of obtaining data about the "primitive" mind of prehistoric man. ${ }^{49}$ Vygotsky also accepted Thurnwald's point of view that the cultural inferiority of these people was not necessarily caused by biological factors: their anatomy and physiology were not greatly different from ours. In fact, whereas Thurnwald had written that the evidence for this was not conclusive, Vygotsky referred to him as claiming that no biological differences whatsoever did exist. This is of considerable importance as it was the only evidence Vygotsky ever obtained for his claim that the lower psychological process, presumably closely tied to the biological makeup, were identical for all human beings in different cultures and epochs. 
However, Vygotsky's selection of cultural phenomena in discussing the differences between various cultures was quite different from Thurnwald's. He significantly narrowed Thurnwald's concept of culture by concentrating on the phenomena of language, counting systems, and writing, and ignoring his other subjects, such as the different systems of law, moral thinking, art, and religion. There may have been three, interconnected, reasons for this particular selection of relevant cultural phenomena. In the first place, a distinction is possible between social, "soft," and technological, "hard," cultural evolution. ${ }^{50}$ Social evolution includes the changes in forms of law and government, economics, the family, music, art, and religion. Technology is the discovery and implementation of methods by which human beings can act on their environment. Its success depends on the manipulation of the laws of nature. It uncovers the laws of nature and seeks to manipulate them. Keeping this distinction in mind one immediately sees that Vygotsky ignored all cultural phenomena belonging to social evolution. The reason for this selection seems clear: there is very little evidence for progress in this domain of culture. ${ }^{51}$ The case seems different for the topics Vygotsky selected: writing systems, counting systems, and language. To Vygotsky and his contemporaries, at least, it seemed obvious that, for example, using body parts to count was more limited than counting with the use of written numbers. Also, the evidence gathered by Lévy-Bruhl and other anthropologists seemed to indicate that the natives' languages were definitely inferior as regards the possibility of forming abstract concepts. Thus, Vygotsky selected those aspects of culture that were milestones in human history and with regard to which the notion of cultural progress was intuitively more plausible. Second, literacy and counting systems could be thought of as sign systems that served a double function. Counting systems and written and spoken language not only served a definite function in the external world, say, the preservation of tradition in written texts, but also served as instruments for the growing control of human behavior. Just like tools that transformed the inanimate universe, they were sign systems that transformed our mental functioning. ${ }^{52}$ Third, the selection of cultural procedures that might be thought of as tools was, naturally, much influenced by Marx's and Engels' account of the history of man. Tool use and language were considered, as we have seen, as defining characteristics of man. ${ }^{53}$ 
Thus, for the sake of comparing cultures, Vygotsky selected technology due to the way it had radically changed the outlook of Western cultures, while no progress was evident in other aspects of culture. The choice of these aspects nicely fitted in with Marxist anthropology.

Unfortunately, this particular selection of phenomena for crosscultural comparison made Vygotsky particularly vulnerable to the tendency, already present in Thurnwald's thinking, to rank different cultures on a linear scale. In fact, he did this in various publications, an approach that was to bring him much criticism. For example, he claimed that the level of societal and cultural development of national minorities, such as the Islamic culture in Uzbekistan, was "low. ${ }^{54}$ Within the next five years, it was the time of the first five-year-plan, these cultures had to "take a grandiose leap on the ladder of their cultural development, jumping over a whole series of historical levels." Vygotsky also characterized the national minorities as "backward" and judged a "forced cultural development" to be essential in order to reach "a unified socialist culture." 55

In defense of Vygotsky, however, it should be remarked that emphasizing culture as the underlying cause of mental differences between people of different cultures had its positive aspects. On the basis of the writings of Lévy-Bruhl and Thurnwald, Vygotsky rejected the idea, defended by such contemporaries as Burt, Terman, and Yerkes, that different mental performances could be fully explained by biological factors. He saw clearly that mental tests can never be culturally impartial and criticized their use in judging the mental abilities of non-Western people. He insisted that the mental functioning of persons should always be judged against the background of their culture and personal circumstances. ${ }^{56}$

Summarizing, it can be said that, on the basis of his reading of Thurnwald, Vygotsky definitely agreed with many of his contemporaries in characterizing different cultures as "superior" and "inferior." His selection of cultural topics to be considered for cross-cultural comparisons was rather one-sided and tended to favor Western culture. Unlike many of his colleagues, he avoided the mistake of explaining cultural and mental differences by referring to biological or even racial differences. 


\section{Making Use of Thurnwald's Ethnographic Observations}

Thurnwald's study not only provided Vygotsky with a way of thinking about culture and its relation to the human mind; as in the case of Lévy-Bruhl's writings, it also served as a source of knowledge about other cultures. Most importantly, Thurnwald discussed several findings that Vygotsky could use for his idea that sign systems served a double function and that they were similar in some sense to tools.

Of most interest were Thurnwald's discussions of primitive memory aids, counting, and writing systems. With regard to counting systems he noticed ${ }^{57}$ that primitive counting was very much tied to concrete images and that numerals were frequently seen as names for a concrete set of objects. Concrete objects or animals, often served as numerals, for example a crocodile because of the number of its teeth; and in many cultures counting procedures made use of body parts. In general, then, the counting systems were no more abstract and decontextualized than allegedly the primitive language. ${ }^{58}$ Thurnwald also observed that "primitive" people would not accept tasks that were far from their concrete everyday life experiences. One subject, for example, whom Thurnwald ${ }^{59}$ had requested to count as far as he could using imaginary pigs as a unit, refused to count over 60 as greater numbers of pigs were simply unrealistic. Thurnwald concluded that "primitives" were very much tied to concrete reality and refused abstract tasks, a phenomenon that Luria would observe again in his expeditions to Uzbekistan. ${ }^{60}$

Thurnwald discussed different memory aid system $\mathrm{s}^{61}$ in great detail and he considered them as the origin of our current writing systems. According to him, memory aids originated as individual means to overcome time and gradually became conventionalized as means of communication within a community ${ }^{62} \mathrm{He}$ discussed various systems mentioning in passing the example that became Vygotsky's favorite, viz., a knot in a handkerchief. It is significant that four of Thurnwald's illustrations demonstrating various primitive coding systems, such as the Peruvian Quippu system of tying knots in a string, were reproduced in the second chapter of Studies of the History of Behavior. ${ }^{63}$ In the same book Vygotsky cited Thurnwald's discussion of the various writing systems and the development from pictographic to ideographic systems, and these data clearly influenced his and Luria's research. Luria's 
study ${ }^{64}$ of the development of writing in the child, for example, was an attempt to show that contemporary children, too, go through a pictographic and ideographic phase in their symbolic activity.

It is interesting to see that Vygotsky, as a rule, was somewhat more inclined to interpret Thurnwald's ethnographic findings in an evolutionary, developmental way than Thurnwald himself. An example can best illustrate Vygotsky's reasoning in this respect. Having discussed the "African habit" of transmitting important messages by a messenger who reproduces the message word by word, Vygotsky compared this system to the Quippu system and concluded:

One has only to compare the memory of the African messenger, who ... makes exclusive use of his natural eidetic memory, with the memory of the Peruvian "officer of knots," whose task it was to tie and read the Quippu, in order to see the direction in which the development of human memory goes as culture develops. ..."

What Vygotsky implied here is that very "primitive" people remembered things by retaining the vivid, concrete experience of the event, the mneme, while culturally more advanced people developed technical means to do the same. In doing so they developed a "memoria technica" that replaced natural, eidetic memory and would eventually contribute to its decay. Of course, the suggestion was that a similar development would be discernible in child development.

\section{Conclusion}

The views and findings of contemporary anthropological thinkers such as Durkheim, Lévy-Bruhl, and Thurnwald integrated into a Marxist framework provided Vygotsky with a solid anthropological underpinning for his cultural-historical theory. In this paper I have shown that, although Vygotsky selectively borrowed from these thinkers, he depended extensively on their writings in his view of the history of modern man and his relation to both historical and contemporary "primitives."

The resulting view of contemporary Western man was rather optimistic. Human history was on the one hand the history of (Western) man's growing dominion over nature through the invention of tools and the perfection of technology; but on the other hand it was also the history of man's gradual mastery of the self through the invention of 
"the cultural technique of signs." 66 Thus, the optimistic conclusion to be drawn from Vygotsky's account of human history was that one could see definite progress in two respects: modern man surpassed his precursors (and non-Western man) through a) his superior domination of nature through technology, and b) his improved mastery of the self through "psychotechnology." It would take World War II and the later consciousness of environmental pollution to make people seriously doubt these claims.

Vygotsky's view of cross-cultural differences between persons' mental functioning differed from several well-known positions. Unlike his contemporaries Spencer and Stanley Hall, he denied the existence of any genetic differences between the members of different cultures. Contrary to anthropologists such as Bastian, Tylor and Frazer, ${ }^{67}$ and contemporary structuralist thinkers such as Levi-Strauss, ${ }^{68}$ he was of the opinion that the thinking of people belonging to different cultures differed fundamentally. In his opinion both the content and form of human thinking were based on the available, cultural symbolic systems.

In so far as Vygotsky ranked persons belonging to different cultures on an imaginary evolutionary ladder, it was a ranking based not on genetic, or racial, differences, but on the supposedly different qualities of their respective cultures. He did think, together with many of his contemporaries, that it was possible to compare cultures in a global fashion and to order them on some sort of cultural ladder. Debatable as this view may now seem, it harmonized with the general optimistic framework of that time: people of the various "backward" cultures of the Soviet Union might be (re)educated within the relatively short period of a few years and thus be liberated from the yoke of the prerevolutionary "feudal" system.

\section{NOTES}

1 Vygotsky, L. S. (1928m), "Problema kul'turnogo razvitija rebenka," Pedologia, 1, 58-77; Vygotsky, L. S. (1929a), "Geneticheskie korni myshlenija i rechi," Estestvoznanie i Marksizm, 1, 106-133; Vygotsky, L. S. (1929b), "K voprosu ob intellekte antropoidov v svjazi s rabotami V. Kolera, "Estestvoznanie i Marksizm, 2, 131-153; Vygotsky, L. S. (1929c), "The problem of the cultural development of the child II," Journal of Genetic Psychology, 36, 415-434; Vygotsky, L. S. (1929d), "K voprose o plane nauchnoissledovatel'skoj raboty po pedologii nacional'nykh men'shinstv," 
Pedologija, 3, 367-377; Vygotsky, L. S. (1929e), Pedologija podrostka, Moscow: BZO; Vygotsky, L. S. (1930/1960), Povedenie zhivotnykh i cheloveka. In L. S. Vygotsky, Razvitie vysshikh psikhicheskikh funkcij (pp. 395-457). Moscow: Izdatel'stvo Pedagogicheskikh Nauk; Vygotsky, L. S. (1931/1983), Istorija razvitija vysshikh psikhicheskikh funkcij. In L. S. Vygotsky, Sobranie sochinenij. Tom 3. Problemy razvitija psikhiki (pp. 6-328). Moscow: Pedagogika; Vygotsky, L. S. \& Luria, A. R. (1930a/ 1984), Orudie i znak. In L. S. Vygotsky, Sobranie sochinenij. Tom 6. Nauchnoe nasledstvo (pp. 6-90). Moscow: Pedagogika.

2 Vygotsky, L. S., \& Lurija, A. R. (1930b), Etiudy po istorii povedenija. Obezjana. Primitiv. Rebenok, Moskva-Leningrad: Gosudarstvennoe Izdatel'stvo.

${ }^{3}$ Barash, D. P. (1986), The Hare and the Tortoise. Culture, Biology, and Human Nature. Harmondsworth: Penguin. Hinde, R. A. (1982), Ethology. Glasgow: Fontana; Tinbergen, N., \& Tinbergen, E. A. (1983), "Austistic" Children. New Hope For a Cure, London: George Allen \& Unwin; Wilson, E. O. (1976), Sociobiology. The New Synthesis, Cambridge, Mass.: The Belknap Press of Harvard University Press.

${ }_{4}$ Van der Veer, R., \& Valsiner, J. (1991), Understanding the Quest For Synthesis, Oxford: Basil Blackwell.

${ }^{5}$ Bühler, K. (1919), Abriss der geistigen Entwicklung des Kindes, Leipzig: Verlag Von Quelle \& Mener.

${ }_{6}^{6}$ Freud, S. (1913/1956), Totem und Tabu, Frankfurt a/M: Fischer Taschenbuch Verlag.

7 Kafka, G. (Ed.) (1922), Handbuch der vergleichenden Psychologie, Munchen: Verlag von Ernst Reinhardt.

${ }^{8}$ Koffka, K. (1925), Die Grundlagen der psychischen Entwicklung. Eine Einführung in die Kinderpsychologie, Osterwieck am Harz: A. W. Zickfeldt.

${ }^{9}$ Kretschmer, Ek. (1916), Körperbau and Charakter, Berlin: Verlag von Julius Springer,

10 Stern, W. (1927), Psychologie der frühen Kindheit bis zum sechsten Lebensjahre, Leipzig: Quelle \& Meyer.

11 Werner, H. (1925), Einführung in die Entwicklungspsychologie, Leipzig: J. A. Barth.

12 Freud, S. (1913/1956), Totem und Tabu; p. 9.

13 Kafka, G.(Ed.) (1922), Handbuch der vergleichenden Psychologie.

${ }^{14}$ Koffka, K. (1925), Die Grundlagen der psychischen Entwicklung; p. 1-2.

15 Darwin, Ch. (1871/1981), The Descent of Man, and Selection in Relation to Sex, Princeton, NJ: Princeton University Press; p. 186.

16 Marx, K. (1981), Das Kapital. Kritik der politischen Ökonomie, Berlin: Dietz Verlag; p. 194.

${ }_{17}$ Engels, F. (1978), Dialektik der Natur, Berlin: Dietz Verlag.

18 Ibid., p. 444-455.

19 Ibid., p. 444.

20 Ibid., p. 447.

${ }^{21}$ Vygotsky (1934), Myshlenie $i$ rech. Psikhologicheskie issledovanija, MoscowLeningrad: Gosudarstvennoe Social'no-Ekonomicheskoe Izdatel'stvo; p. 59.

22 Van der Veer, R., \& Valsiner, J. (1988), "Lev Vygotsky and Pierre Janet: On the origin of the concept of sociogenesis," Developmental Review, 8, 52-65.

${ }^{23}$ Durkheim, E. (1985), Les formes élémentaires de la vie religieuse. Le système totémique en Australie, Paris: Quadrige/P.U.F.; p. 5. 
Ibid., pp. 23-24.

Ibid., p. 27.

26 Ibid., pp. 27-28 (emphasis added).

27 Lévy-Bruhl, L. (1910/1922), Les fonctions mentales dans les sociétés inférieures, Paris: Alcan; p. 1-4.

28 Vygotsky, L. S. \& Lurija, A. R. (1930b), Etjudy po istorii povedenija.

29 Lévy-Bruhl, L. (1910/1922), Les fonctions mentales dans les sociétés inférieures; pp. $6-20$.

${ }^{30}$ Vygotsky, L. S., \& Lurija, A. R. (1930b), Etjudy po istorii povedenija; p. 60.

31 Ibid., p. 64.

32 Luria, A. R. (1974), Ob istoricheskom razvitii poznavatel'nykh processov, Moscow: Nauka; Luria, A. R. (1976), Cognitive Development. Its Cultural and Social Foundations, Cambridge, Mass.: Harvard University Press; Van der Veer, R., \& Valsiner, J. (1991), Understanding Vygotsky. The Quest For Synthesis. Oxford: Basil Blackwell.

${ }^{33}$ Lévy-Bruhl, L. (1910/1922), Les fonctions mentales dans les sociétés inférieures; p. 67.

34 Ibid., p. 39.

35 Lévy-Bruhl, L. (1922/1976), La mentalité primitive, Paris: Retz; p. 67.

36 Ibid., p. $124-130$.

${ }^{37}$ Ibid., p. 203.

38 Lévy-Bruhl, L. (1910/1922), Les fonctions mentales dans les sociétés inférieures; pp. $117-124 ; 151-203$.

39 Vygotsky, L. S., \& Lurija, A. R. (1930b), Etjudy po istorii povedenija, MoskvaLeningrad: Gosudarstvennoe Izdatel'stvo; p. 98.

40 Lévy-Bruhl, L. (1910/1922), Les fonctions mentales dans les sociétés inférieures; pp. 117-124; Lévy-Bruhl, L. (1922/1976), La mentalité primitive; pp. 35-37.

${ }^{41}$ Vygotsky, L. S. (1931/1983), Istorija razvitija vysshikh psikhicheskikh funkcij. In L. S. Vygotsky, Sobranie sochinenij. Tom 3. Probemy razvitija psikhiki, Moscow: Pedagogika; pp. 67-68.

42 Lévy-Bruhl, L. (1922/1976), La mentalité primitive; p. 172; pp. 192-195.

43 Lévy-Bruhl, L. (1910/1922), Les fonctions mentales dans les sociétés inférieures; pp. 204-257.

44 Thurnwald, R. (1922), Psychologie des primitiven Menschen. In G. Kafka (Ed.), Handbuch der vergleichenden Psychologie. Band 1, Munchen: Verlag von Ernst Reinhardt; p. 150.

45 Ibid., p. 154.

46 Cole, M., \& Scribner, S. (1974), Culture and Thought. A Psychological Introduction, New York: Wiley; Berry, J. W., \& Dasen, P. R. (Eds.) (1974), Culture and Cognition: Readings in Cross-Cultural Psychology, London: Methuen; Scribner, S., \& Cole, M. (1981), The Psychology of Literacy, Cambridge: Harvard University Press.

47 Thurnwald, R. (1922), Psychologie des primitiven Menschen; p. 152.

48 Ibid., p. 157.

49 Vygotsky, L. S., \& Lurija, A. R. (1930b), Etjudy po istorii povedenija; p. 58.

so Barash, D. P. (1986), The Hare and the Tortoise. Culture, Biology, and Human Nature, Harmondsworth: Penguin; p. 41.

s1 Ibid., p. 42.

52 Vygotsky, L. S., \& Lurija, A. R. (1930b), Etjudy po istorii povedenija;p. 54. 
53 See Bloch, M. (1983), Marxism and Anthropology. Oxford: Oxford University Press, for an intelligent criticism of Marx' and Engels' anthropological thinking.

${ }^{54}$ Vygotsky, L. S. (1929d). "K voprose o plane nauchno-issledovatel'skoj raboty po pedologii nacional'nykh men'shinstv," Pedologija, 3, 367-377.

55 Ibid., p. 367.

56 Ibid., p. 369.

57 Thurnwald, R. (1922), Psychologie des primitiven Menschen; pp. 273-275.

58 Ibid., p. 269.

59 Ibid., p. 274.

${ }^{60}$ Luria, A. R. (1974), Ob istoricheskom razvitii poznavatel'nykh processov; Luria, A. R. (1976), Cognitive Development.

${ }_{61}$ Thurnwald, R. (1922), Psychologie des primitiven Menschen; pp. 243-265.

62 Ibid.,pp. 243-244.

63 Vygotsky, L. S., \& Lurija, A. R. (1930b), Etjudy po istorii povedenija.

${ }_{64}$ Luria, A. R. (1929/1978), The development of writing in the child. In M. Cole (ed.), The Selected Writings of A. R. Luria (pp. 145-194), White Plains: Merle Sharpe.

${ }_{65}$ Vygotsky, L. S. \& Luria, A. R. (1930b), Etjudy po istorii povedenija; p. 85.

${ }_{66}$ Vygotsky, L. S. (1928m), "Problema kul'turnogo razvitija rebenka," p. 76; Van der Veer, R., \& Valsiner, J. (1991), Understanding Vygotsky.

${ }^{67}$ Klausen, A. M. (1984), Antropologins historia, Stockholm: Norsteds.

${ }_{68}$ Tulviste, P. (1988), Kul'turno-istoricheskoe razvitie verbal'nogo myshlenija, Tallinn: Valgus.

\section{Department of Education}

University of Leiden

Wassenaarseweg 52

2333 AK Leiden

The Netherlands 